\title{
Populasi Hama dan Musuh Alami pada Tiga Cara Budidaya Padi Sawah di Sukamandi
}

\author{
N. Usyati, Nia Kurniawati, Ade Ruskandar dan Oco Rumasa \\ Balai Besar Penelitian Tanaman Padi Sukamandi \\ Jl. Raya No. 9 Sukamandi, Subang, Jawa Barat \\ *Alamat korespondensi: n_usyati06@yahoo.co.id
}

\begin{abstract}
Pest and natural enemy population in three different rice cultivation in Sukamandi Region

Some on limiting factors in rice production include the cultivation system and pest damage. To suppress the damage, several control techniques have been applied, such as technical culture. The aim of this study was to gain information on population and pest damage, as well as natural enemy population in three different rice cultivation systems. The study was arranged in Randomized Block Design with three treatment and 9 replications. The treatments were: 1) organic rice cultivation, 2) semi organic, and 3) farmer technique. The used rice variety was Inpari 30 . The plot size was $6 \mathrm{~m} \times 90 \mathrm{~m}$. The variables observed included population and pest damage, natural enemy population, and rice yields. Thirthy two rice hills were observed randomly in diagonal direction, with 2 weeks interval from two weeks after transplanting until harvest. The data were analyzed by analysis of variance (Anova) and the difference among the treatments was evaluated with Duncan multiple area test at $5 \%$ level. The results showed that brown plant hoppers population on organic rice cultivation is lower than semi-organic rice cultivation and farmer technique, but there were no difference of natural enemy population among treatments. The lowest yield was obtained from the organic rice cultivation $(2.67 \mathrm{t} / \mathrm{ha})$.
\end{abstract}

Keywords: Rice cultivation, Pests, Natural enemies

\begin{abstract}
ABSTRAK
Beberapa faktor pembatas produksi padi diantaranya adalah cara budidaya dan adanya serangan hama. Untuk menekan serangan hama, beberapa teknik pengendalian telah diterapkan diantaranya adalah pengendalian secara kultur teknis (cara budidaya). Pada MT-2 tahun 2016, penelitian dengan tujuan mendapatkan informasi mengenai populasi dan serangan hama, serta populasi musuh alami pada tiga cara budidaya padi telah dilakukan di lahan kebun percobaan Balai Besar Penelitian Tanaman Padi Sukamandi. Rancangan yang digunakan adalah Rancangan Acak Kelompok (RAK) dengan tiga cara budidaya dan diulang sebanyak sembilan kali. Adapun cara budidaya yang digunakan terdiri atas:1) budidaya padi organik; 2) semi organik; 3) cara petani. Varietas yang digunakan adalah Inpari 30. Ukuran plot $6 \mathrm{~m} \mathrm{x} 90 \mathrm{~m}$. Variabel yang diamati meliputi populasi dan tingkat serangan hama, populasi musuh alami, dan hasil panen. Pengamatan dilakukan secara langsung di pertanaman pada 32 rumpun sampel secara acak diagonal dengan interval dua minggu sekali mulai umur tanaman dua minggu setelah tanam sampai menjelang panen. Data yang diperoleh dianalisis dengan analisis ragam (Anova) dan perbedaan antar perlakuan dievaluasi dengan uji wilayah berganda Duncan pada taraf $5 \%$. Hasil penelitian menunjukkan bahwa populasi hama wereng coklat pada cara budidaya padi organik lebih rendah dibandingkan cara budidaya padi semi organik dan budidaya padi cara petani, tetapi tidak ada perbedaan populasi musuh alami pada cara budidaya padi organik, cara budidaya padi semi organik dan budidaya padi cara petani. Hasil panen terendah (2,67 t/ha) terlihat pada perlakuan budidaya padi organik.
\end{abstract}

Kata Kunci: Budidaya padi, Hama, Musuh alami 


\section{PENDAHULUAN}

Tanaman padi merupakan salah satu tanaman pangan utama di Indonesia. Untuk meningkatkan produksi padi, pada tahun 70 -an pemerintah mencanangkan program yang dikenal dengan Revolusi Hijau. Dengan program ini, mulai digunakan varietas unggul, pupuk, pestisida kimia, dan saluran irigasi. Cara budidaya ini dikenal dengan pertanian konvensional. Cara budidaya konvensional di satu sisi terbukti mampu meningkatkan produksi pangan nasional, tetapi disisi lain disinyalir telah menurunkan produktivitas lahan pertanian terutama di daerah-daerah sentra produksi (Kartini, 2001) dan menimbulkan permasalahan lingkungan sebagai dampak dari penggunaan pupuk dan pestisida kimia yang terus menerus dan tidak terkendali (Irvany, 2011).

Untuk menjamin keberlanjutan sistem produksi tersebut diperlukan reorientasi sistem dari sistem konvensional ke sistem pertanian berkelanjutan yang dilandasi oleh prinsip-prinsip ekologi, ekonomi dan sosial di dalam sistem produksinya. Salah satu bentuk sistem pertanian yang dimaksud adalah sistem pertanian organik. Pertanian organik adalah sistem produksi pertanian yang berasaskan daur ulang secara hayati yang mampu memperbaiki status kesuburan dan struktur tanah yang menganut "hukum pengembalian (law of return") yang berarti suatu sistem yang berusaha untuk mengembalikan semua jenis bahan organik ke dalam tanah, baik dalam bentuk residu dan limbah pertanaman maupun ternak, yang selanjutnya bertujuan memberikan makanan pada tanaman dengan mengandalkan bibit lokal dan menghindari penggunaan pupuk dan pestisida kimia sintetis (Sutanto, 2002). Disebutkan bahwa pertanian organik menganut asas kelestarian ekosistem, kemantapan produksi dan keamanan produk serta disebutkan sebagai sistem pertanian yang ramah lingkungan dan berkelanjutan (Hadi dkk., 2014; Prihtanti dkk., 2013; Supartha \& Kartini (2001).

Mengingat batasan pertanian organik yang mempersyaratkan tidak digunakannya pupuk anorganik dan pestisida kimia sintetik, serta lahan yang digunakan harus bebas dari residu kedua agrokimia tersebut, nampaknya usahatani pertanian organik sulit diwujudkan, kecuali di lokasi-lokasi yang sistem usahataninya belum intensif. Alasannya, nutrisi, khususnya $\mathrm{N}$ yang terkandung dalam pupuk organik, tidak mencukupi kebutuhan tanaman. Kandungan $\mathrm{N}$ pada kompos, misalnya kurang 2\% dibandingkan dengan urea yang kandungan $\mathrm{N}$-nya $46 \%$. Selain itu, lahan pertanian umumnya sangat bergantung pada pupuk anorganik, sehingga dikhawatirkan produktivitas tanaman akan merosot dan target produksi tidak akan tercapai. Oleh karena itu, selama program swasembada pangan utama belum tercapai dan terlanjutkan, alternatif pilihan adalah cara budidaya organik rasional yang masih membenarkan penggunaan pupuk anorganik (semi organik) (Arifin, 2012).

Dalam upaya peningkatan produktivitas padi, masih terdapat kendala diantaranya adalah adanya serangan hama. Hama utama yang menyerang tanaman padi diantaranya adalah wereng coklat dan penggerek batang padi. Beberapa hama lainnya yang berpotensi merusak pertanaman padi adalah wereng punggung putih, wereng hijau, lembing batu, ulat grayak, pelipat daun, dan walang sangit (Effendi, 2009). Rata-rata kehilangan hasil produksi pertanian karena serangan OPT $\pm 30 \%$ dari potensi hasil, dan kehilangan hasil karena hama sekitar 20-25\% (Untung, 2010).

Untuk menekan serangan hama, beberapa teknik pengendalian telah diterapkan diantaranya pengendalian secara kultur teknis (cara budidaya), fisik, mekanik, dan kimia. Terkait dengan cara pengendalian secara kultur teknis (cara budidaya), Visalakshmi et al. (2014) menunjukkan bahwa pada budidaya metode System Rice Intensification (SRI) intensitas serangan penggerek batang dan ganjur serangannya lebih rendah dibandingkan pada metode konvensional dengan masing-masing serangan sundep $(6,1 \%: 15,6 \%)$; beluk $(7,2 \%$ : $11,9 \%$ ), dan ganjur $(74,1 \%: 7,1 \%)$. Chandramani et al. (2010) juga menyatakan bahwa penggunaan bahan organik sebagai nutrisi tanaman dapat menurunkan keberadaan hama penggulung daun, penggerek batang padi, dan orong-orong. Hasil penelitian Chakraborthy (2011) menunjukkan bahwa ngengat penggerek batang padi dan kelompok telur ditemukan paling rendah pada perlakuan dengan bahan organik (vermikompos 2,5 t). Selain itu hasil penelitian dari Pajarina (2014) menunjukkan bahwa perkembangan populasi hama wereng coklat, walang sangit, dan wereng hijau pada sistem padi organik lebih rendah dibandingkan dengan sistem padi konvensional. Penelitian ini bertujuan untuk mendapatkan informasi mengenai populasi dan serangan hama, serta populasi musuh alami pada tiga cara budidaya padi sawah yang meliputi cara budidaya padi organik, cara budidaya padi semi organik dan budidaya padi cara petani.

\section{BAHAN DAN METODE}


Penelitian dilakukan di lahan kebun percobaan Balai Besar Penelitian Tanaman Padi Sukamandi pada MT-2 tahun 2016. Rancangan yang digunakan adalah Rancangan Acak Kelompok (RAK) dengan tiga perlakuan cara budidaya yang diulang sebanyak sembilan kali. Adapun cara budidaya yang digunakan terdiri atas: 1) budidaya padi organik, 2) budidaya padi semi organik, dan 3) budidaya padi cara petani. Komponen yang digunakan pada cara budidaya organik adalah pupuk kandang (5 t/ha), biodekomposer (Mdec 51/ha), seedtreatment (Agrimeth $500 \mathrm{~g} / 25 \mathrm{~kg}$ benih), jajar legowo (25 cm x $12,5 \mathrm{~cm} \times 50 \mathrm{~cm}$ ), pestisida nabati, dan penggunaan mol. Pada budidaya semi organik komponen yang digunakan sama dengan budidaya organik di tambah pupuk Urea dan Phonska setengah dosis anjuran. Pada budidaya petani komponen yang digunakan adalah cara tanam tegel $(25 \mathrm{~cm} \quad \mathrm{x} \quad 25 \mathrm{~cm})$, penggunaan pupuk, dan pestisida kimia. Varietas yang digunakan adalah Inpari 30. Ukuran plot $6 \mathrm{~m} \mathrm{x}$ $90 \mathrm{~m}$. Variabel yang diamati meliputi populasi dan tingkat serangan hama, populasi musuh alami, dan hasil panen. Pengamatan dilakukan secara langsung di pertanaman pada 32 rumpun sampel secara acak diagonal dengan interval dua minggu sekali mulai umur tanaman dua minggu setelah tanam sampai menjelang panen. Data yang di peroleh dianalisis dengan analisis ragam (Anova) dan perbedaan antar perlakuan di evaluasi dengan uji wilayah berganda Duncan pada taraf 5\% dengan menggunakan perangkat lunak SAS Institute (1990).

\section{HASIL DAN PEMBAHASAN}

\section{Hama Utama}

Hama yang terdapat di pertanaman selama penelitian diantaranya adalah wereng coklat (Nilaparvata lugens Stahl) dan penggerek batang padi kuning (Scirpophaga incertulas Wlk). Hasil pengamatan menunjukkan bahwa populasi wereng coklat nyata lebih tinggi pada perlakuan budidaya padi semi organik dibandingkan dengan perlakuan lainnya di awal pertanaman (2 MST; $(\mathrm{P}=<0,0001)$ dan 4 MST $(\mathrm{P}=0,0001))$, dengan rata-rata berkisar 107,67-2693,0 ekor/32 rumpun. Pada pengamatan selanjutnya populasi wereng coklat terus menurun dan tidak berbeda antar perlakuan (Gambar 1).

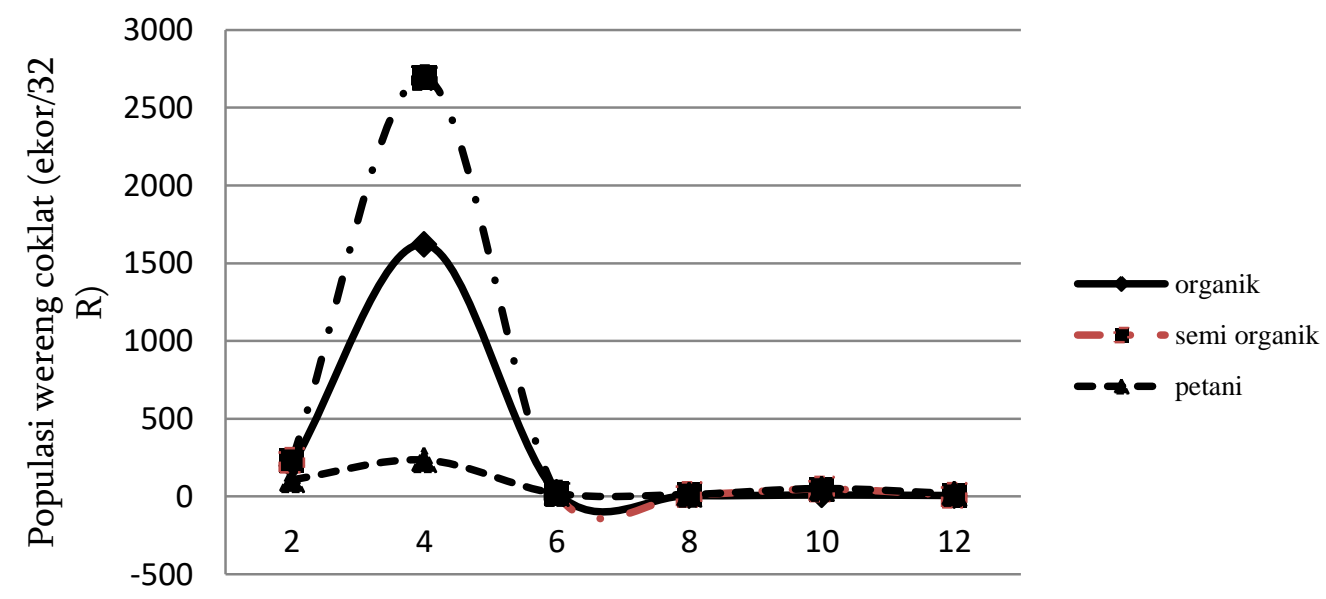

Minggu setelah tanam

Gambar 1. Populasi wereng coklat pada tiga cara budidaya padi. Sukamandi, MT 2 tahun 2016.

Ngengat penggerek batang padi kuning $(S$. incertulas Wlk) baru ditemukan pada 8 MST dengan populasi rendah. Dari ketiga perlakuan, populasi ngengat penggerek batang padi kuning (PBPK) tertinggi terlihat pada perlakuan budidaya padi semi organik dengan rata-rata populasi berkisar 2,0-2,78 ekor/32 rumpun $(P=0,0005)$. Pada pengamatan selanjutnya populasi ngengat penggerek batang padi kuning terus menurun dan tidak berbeda antar perlakuan (Gambar 2). 


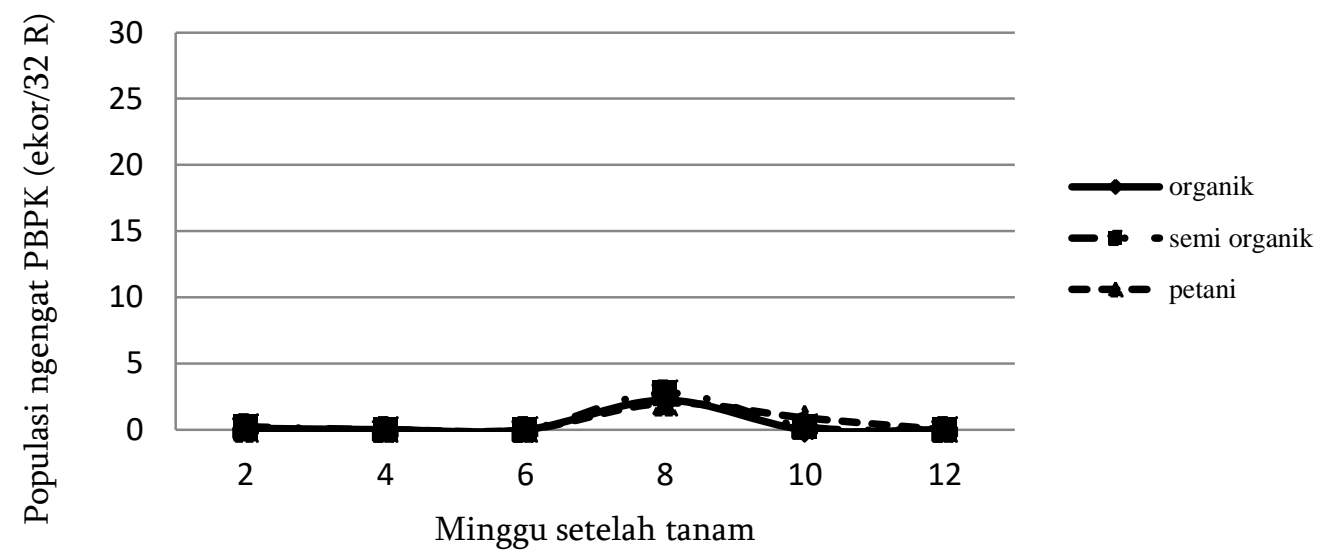

Gambar 2. Populasi ngengat PBPK pada tiga cara budiddaya padi. Sukamandi, MT 2 tahun 2016.

Gejala serangan penggerek batang padi kuning ( $S$. incertulas Wlk) (PBPK) mulai terlihat pada akhir pertanaman (10 MST). Hasil pengamatan menunjukkan bahwa populasi ngengat dan intensitas serangan penggerek batang padi kuning rendah pada ketiga perlakuan dengan rata-rata berkisar 0,14\%-2,31\% (Gambar 3).

Fluktuasi populasi hama sifatnya dinamis, dapat naik turun tergantung ketersediaan pakan di lapangan dan lingkungan yang mendukung (Natawigena, 1990), serta adanya migrasi dari tempat lain yang populasinya tinggi dan ketersediaan pakan kurang. Selain itu dapat juga disebabkan karena berkurangnya musuh alami (predator dan parasitoid) sehingga terjadi ketidakseimbangan ekosistem.

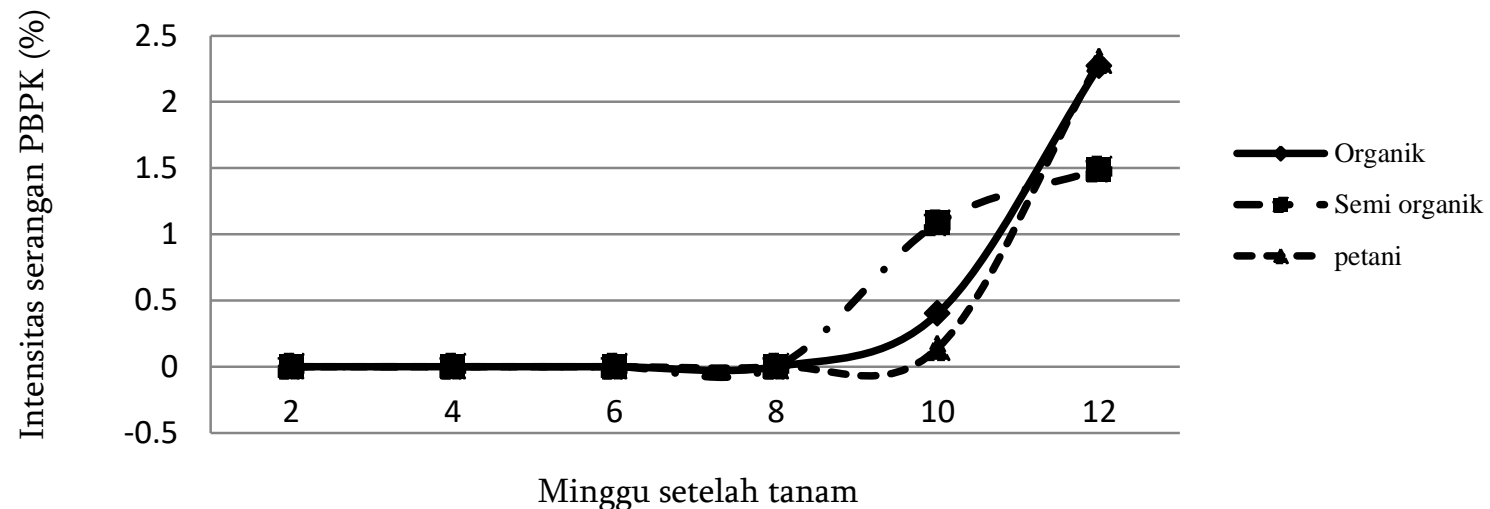

Gambar 3. Intensitas serangan PBPK (\%) pada tiga cara budidaya padi. Sukamandi, MT 2 tahun 2016.

Berdasarkan hasil pengamatan pada perlakuan ini terlihat bahwa populasi wereng coklat tinggi pada awal pertanaman, namun kemudian terus menurun hingga akhir pengamatan. Pada pengamatan $4 \mathrm{MST}$, populasi wereng coklat terlihat lebih tinggi pada perlakuan budidaya padi semi organik dibandingkan budidaya padi organik dan cara petani. Hal ini disebabkan pada perlakuan budidaya padi semi organik, tanaman padi selain diberi bahan organik juga diberikan pupuk kimia (NPK) yang meningkatkan kadar nitrogen dalam tanaman yang akan lebih disukai oleh wereng coklat. Selain itu pengendaliannya dilakukan dengan menggunakan insektisida nabati yang memberikan efek lebih lambat dalam menurunkan populasi wereng coklat. Menurunnya populasi wereng coklat 
pada pengamatan berikutnya disebabkan adanya tindakan pengendalian baik dengan bahan nabati (organik + semi organik) maupun insektisida kimia.

Penggerek batang padi kuning (PBPK) pada semua perlakuan baru terlihat diakhir pertanaman dengan populasi rendah. Hal ini diduga disebabkan sejak awal wereng coklat telah ada di pertanaman dengan populasi yang cukup tinggi sehingga sulit bagi penggerek batang padi untuk dapat berkembang atau bersaing, sedangkan di akhir pertanaman populasi wereng coklat terus menurun sejalan dengan dilakukannya tindakan pengendalian. Gejala serangan penggerek batang padi kuning (PBPK) baru terlihat pada 10 dan 12 MST. Hal ini terkait dengan biologi serangga hama PBPK dimana ngengat mulai terlihat di lapangan pada 8 MST dan gejala serangan biasanya mulai terlihat pada dua minggu setelah ada penerbangan.

\section{Musuh Alami}

Musuh alami yang terdapat di pertanaman selama penelitian adalah laba-laba, Paederus, Coccinella, dan Cyrtorhinus. Hasil pengamatan menunjukkan bahwa populasi laba-laba pada ketiga perlakuan rendah dengan rata-rata berkisar 7,5617,00 ekor/ 32 rumpun. Pada pengamatan 2 dan 4 MST, populasi laba-laba terlihat nyata lebih tinggi pada perlakuan budidaya padi organik dibandingkan dua perlakuan lainnya $(\mathrm{P}=0,0001$; $\mathrm{P}=0,0092$ ). Pada pengamatan selanjutnya populasi laba-laba terlihat rendah dan tidak berbeda antar perlakuan (Gambar 4).

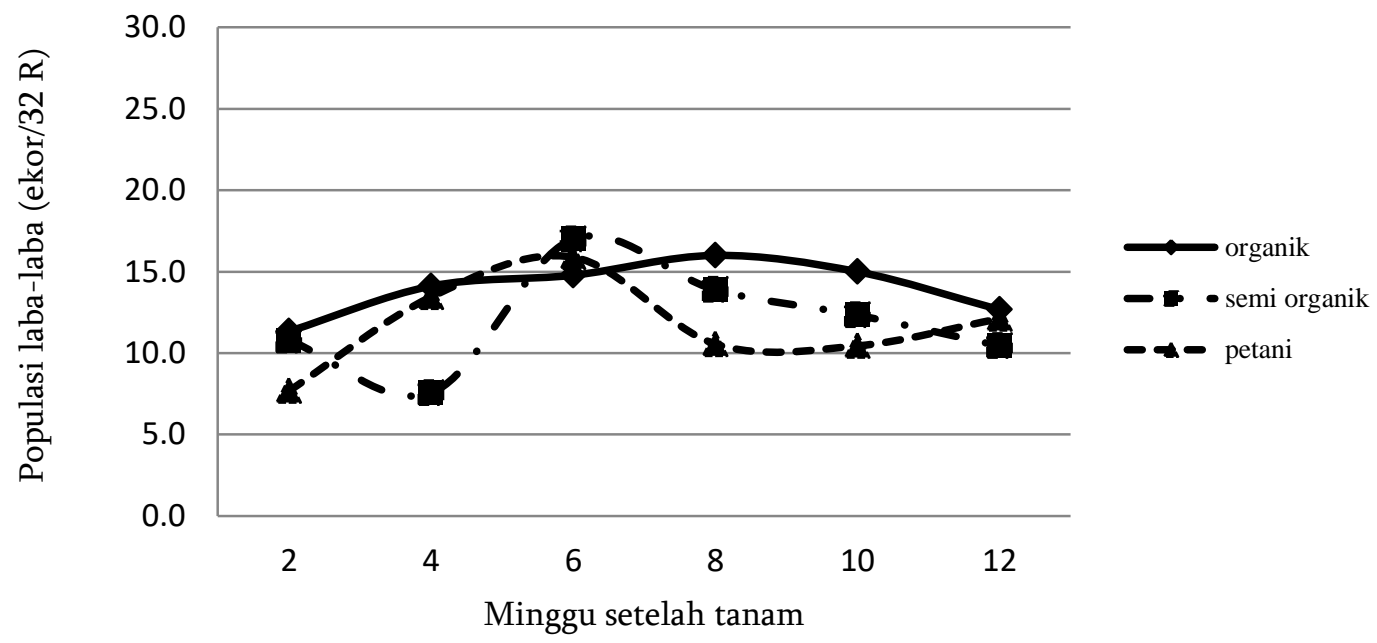

Gambar 4. Populasi laba-laba pada tiga cara budidaya padi. Sukamandi, MT 2 tahun 2016.

Hasil pengamatan menunjukkan bahwa populasi Paederus sudah terlihat sejak awal pertanaman dengan populasi rendah, dengan ratarata berkisar 0,00-23,67 ekor/32 rumpun. Pada pengamatan 2 MST, populasi Paederus terlihat nyata lebih tinggi pada perlakuan budidaya padi organik dibandingkan dengan dua perlakuan lainnya $(\mathrm{P}=0,07)$. Namun pada pengamatan $4 \mathrm{MST}$, populasi Paederus pada perlakuan budidaya padi organik terlihat lebih rendah dibandingkan dengan dua perlakuan lainnya $(P=0,0001)$. Pada pengamatan selanjutnya populasi Paederus terlihat tidak berbeda antar perlakuan (Gambar 5).

Berdasarkan hasil pengamatan terlihat bahwa populasi Coccinella juga rendah pada semua perlakuan, dengan rata-rata populasi berkisar 0,00 11,33 ekor/32 rumpun. i awal pertanaman/stadia vegetatif (2-6 MST), populasi Coccinella pada perlakuan budidaya padi organik terlihat lebih rendah dibandingkan dengan budidaya padi semi organik dan budidaya padi cara petani. Tetapi sebaliknya pada stadia generatif (8-12 MST), populasi Coccinella terlihat nyata lebih tinggi pada perlakuan budidaya padi organik dibandingkan dengan dua perlakuan lainnya (Gambar 6).

Populasi Cyrtorhinus yang merupakan musuh alami spesifik dari wereng coklat terlihat sama dengan populasi wereng coklat. Rata-rata populasi Cyrtorhinus berkisar 7,11-107,11 ekor/32 rumpun. Puncak populasi Cyrtorhinus terlihat pada pengamatan 4 MST. Pada pengamatan tersebut populasi Cyrtorhinus pada perlakuan budidaya padi semi organik $(107,11)$ terlihat nyata lebih tinggi dibandingkan dengan budidaya cara petani, namun tidak berbeda dibandingkan dengan budidaya padi organik $(P=0,0001)$. Populasi Cyrtorhinus pada 
pengamatan selanjutnya terus menurun dan tidak adanya tindakan pengendalian (Gambar 7). berbeda antar perlakuan. Hal ini diduga dikarenakan

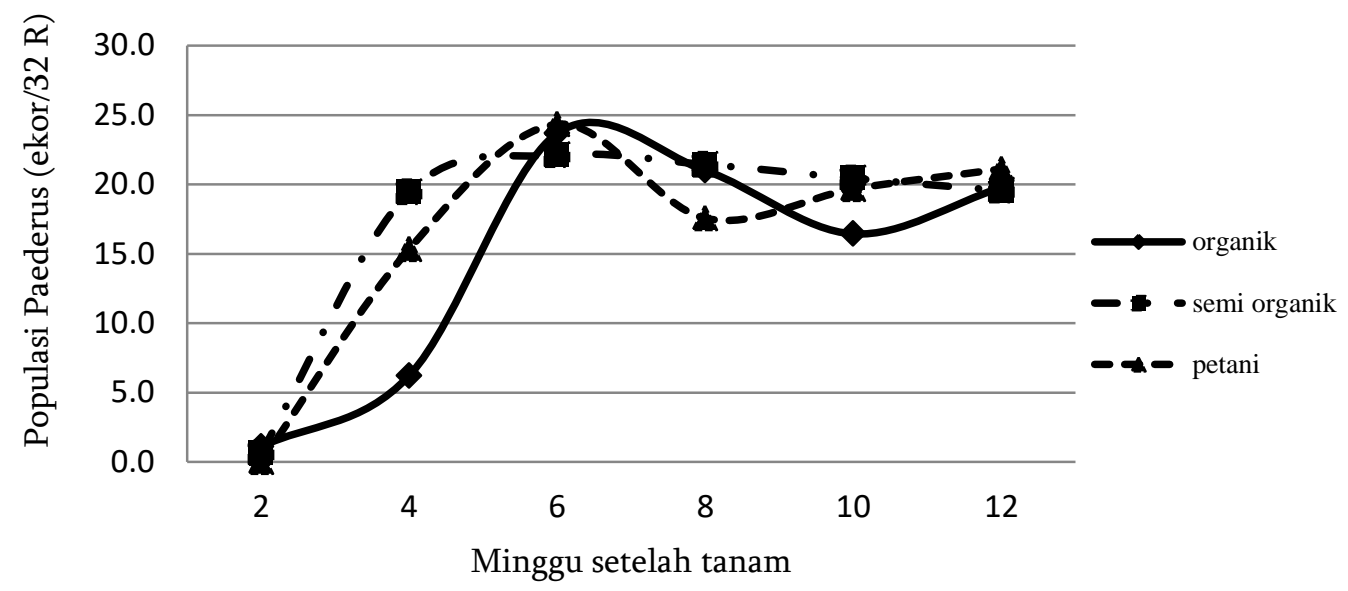

Gambar 5. Populasi Paederus pada tiga cara budidaya padi. Sukamandi, MT 2 tahun 2016.

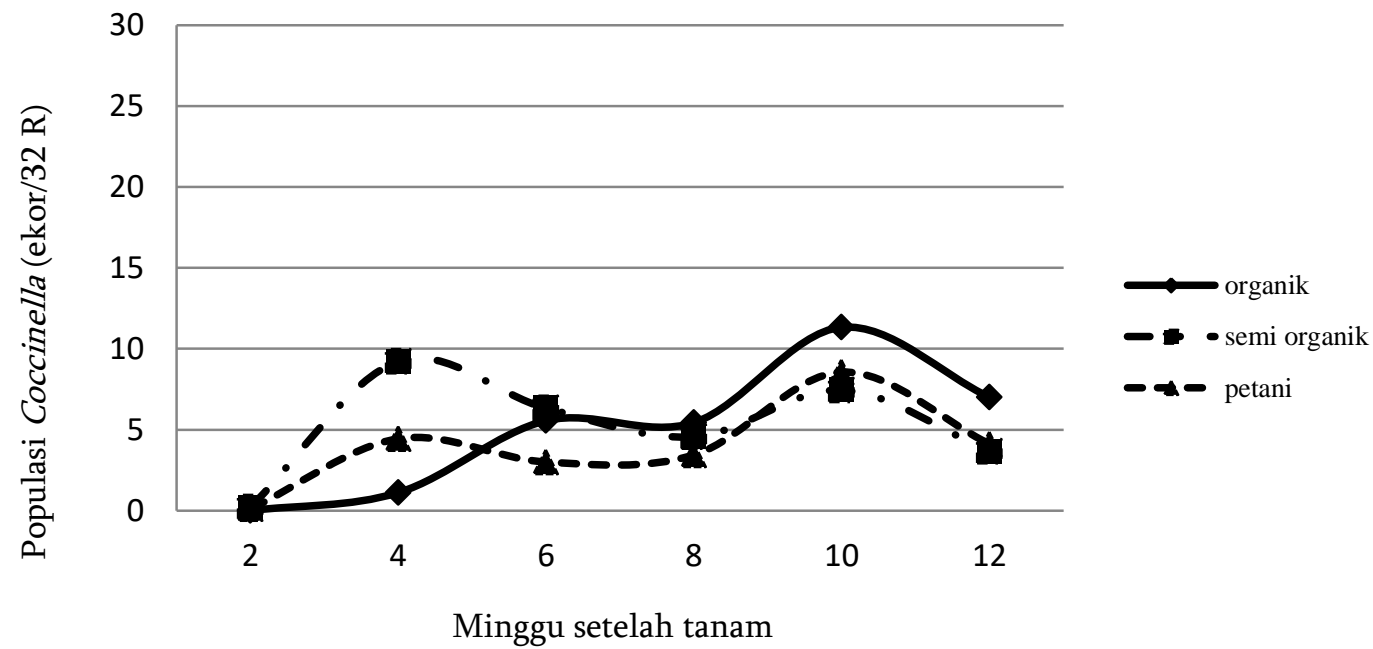

Gambar 6. Populasi Coccinella pada tiga cara budidaya padi. Sukamandi, MT 2 tahun 2016.

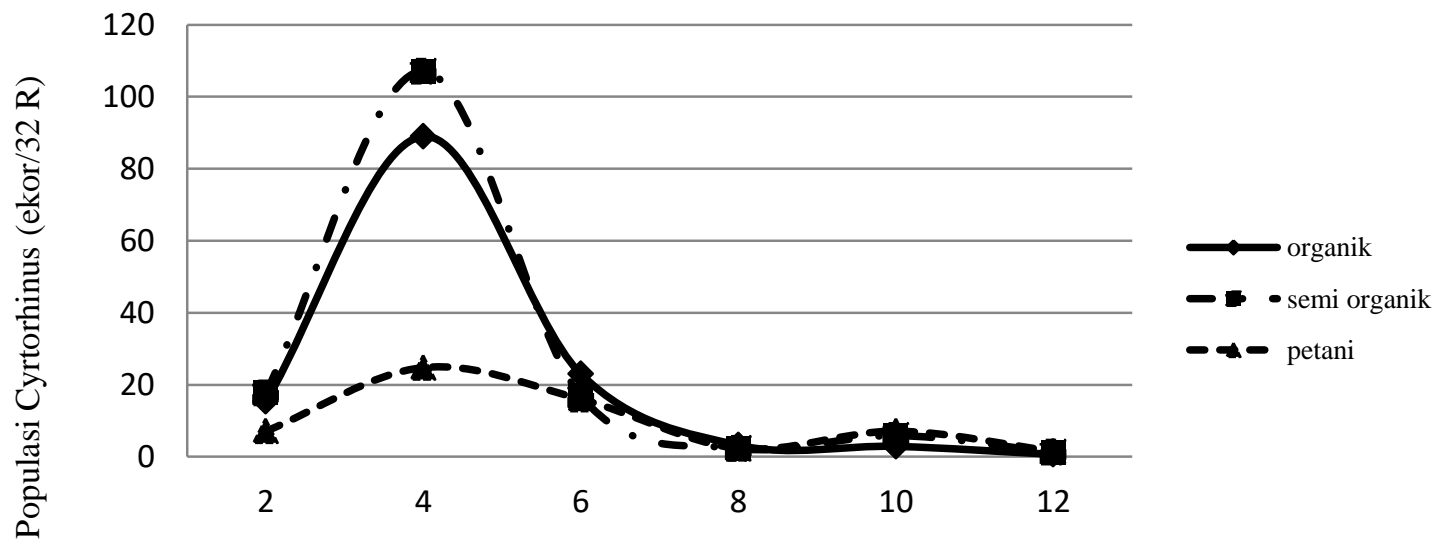

Minggu setelah tanam

Gambar 7. Populasi Cyrtorhinus pada tiga cara budidaya padi. Sukamandi, MT 22016 
Populasi musuh alami baik laba-laba, Paederus, Coccinella, dan Cyrtorhinus terlihat rendah pada semua perlakuan. Hal ini diduga karena lahan organik dan semi organik yang tidak terisolasi atau berdekatan dengan lahan petani yang pengendalian hamanya dilakukan secara intensif, dan hal ini memungkinkan lahan organik dan semi organik terpapar juga oleh insektisida yang diaplikasikan petani. Berbeda dengan hasil penelitian ini, hasil penelitian Bengtsson dkk, (2005) menunjukkan bahwa sistem pertanian organik memiliki efek positif pada kekayaan spesies dan kelimpahan, namun pengaruhnya cenderung berbeda antara kelompok organisme dan lanskap.

\section{Hasil Panen}

Hasil panen gabah kering giling (GKG) pada perlakuan budidaya padi organik terlihat nyata lebih rendah dibandingkan dengan dua perlakuan lainnya $(\mathrm{P}=0,001)$ (Tabel 1). Pada penelitian ini terlihat juga bahwa hasil panen pada perlakuan budidaya padi organik adalah terendah dibandingkan dengan dua perlakuan lainnya. Hasil penelitian ini sejalan dengan pernyataan Baker et al. (2015), yang menyatakan bahwa dalam pertanian organik yang masih menjadi kelemahan adalah rendahnya hasil panen yang diperoleh.

Tabel 1. Hasil panen gabah kering giling pada tiga cara budidaya padi. Sukamandi, MT 2 tahun 2016.

\begin{tabular}{l|c}
\hline \multicolumn{1}{c|}{ Perlakuan } & Hasil panen GKG (t/ha) \\
\hline $\begin{array}{l}\text { Budidaya padi organik } \\
\text { Budidaya padi semi } \\
\text { organik } \\
\text { Budidaya padi cara petani }\end{array}$ & $2,67 \mathrm{~b}$ \\
\hline
\end{tabular}

Keterangan: Angka-angka yang diikuti huruf yang sama dalam satu kolom tidak berbeda pada taraf 5\% uji DMRT.

Selain itu hasil penelitian Suprijadi \& Abdulrachman (1999) menyatakan bahwa pemberian bahan organik (pupuk kompos) pada berbagai dosis tidak berpengaruh terhadap peningkatan hasil yang ditunjukkan dengan tidak berbedanya jumlah anakan efektif, panjang malai, bobot 1000 butir, dan hasil gabah. Dalam pertanian organik, masa konversi/masa transisi berlangsung selama 2-3 tahun sebelum panen pertama. Kesuburan tanah dan keadaan biologi tanah harus dipertahankan dan ditingkatkan secara sepadan dengan penanaman legume, penambahan bahan organik ke dalam tanah baik dalam bentuk bahan yang telah dikomposkan/tidak (Hadi dkk., 2015). Pertanian organik memang tidak memberikan reaksi instan pada hasil-hasil pertanian, akan tetapi dengan pelaksanaan pertanian organik akan membawa pertanian berjangka panjang dan memberikan solusi bagi tersedianya bahan pangan yang sehat.

\section{SIMPULAN}

Dari hasil penelitian ini dapat disimpulkan:

1. Populasi hama wereng coklat pada cara budidaya padi organik lebih rendah dibandingkan cara budidaya padi semi organik dan budidaya padi cara petani.

2. Tidak ada perbedaan populasi musuh alami pada cara budidaya padi organik, cara budidaya padi semi organik dan budidaya padi cara petani.

3. Hasil panen terendah terlihat pada perlakuan budidaya padi oranik.

\section{DAFTAR PUSTAKA}

Arifin, dan Muhamammad. 2012. Pengendalian Hama Terpadu: Pendekatan dalam mewujudkan pertanian organik rasional. IPTEK Tanaman Pangan. Halaman 98-107.

Baker, BP, D Cooley, S Futrell, L Garling, G Gershumy, TA Green, J Moyer, EG Rajotte, AJ Seaman, and SL Young. 2015. Organic Agriculture and Integrated Pest Management A Synergistic Partnership to Improve Sustainable Agriculture and Food Systems. National Organic And Ipm Working Group. 40 Pp.

Bengtsson, J, J Ahnstrom, and AC Weibull. 2005. The efeets of organic agriculture on biodiversity and abundance: A metaanalysis. Journal of Applied Ecology. 42:261-269.

Chakraborthy, K. 2011. Extent of Yellow stem borer Scirpophaga incertulas (Walker) infestation under different proportional application of organic and inorganic fertilizer in paddy cultivar Swarna Mashuri (MTU 7029). Academic Journal of Entomology. 4(1): 710.

Chandramani, P, R.Rajendran, C Muthiah, and C Chiniah. 2010. Organic source induced silica on leaf folder, stem borere, and gall midge population and rice yield. Journal Biopesticides. 3(2): 423-427.

Effendi, BS. 2009. Strategi pengendalian hama terpadu tanaman padi dalam perspektif praktek pertanian yang baik (Good Agricultural Practices). Jurnal Pengembangan Inovasi. 2(1): 65-78. 
Hadi, M, RCH Soesilohadi, FX Wagiman, dan Y Rahayuningsih. 2014. Pertanian organik suatu alternatif pengelolaan ekosistem sawah yang sehat, alami dan ramah lingkungan. Buletin Anatomi dan Fisiologi. 22(1):72-77.

Hadi, M, RCH Soesilohadi, FX Wagiman, YR Suhardjono. 2015. Populasi penggerek batang padi pada ekosistem sawah organik dan sawah an organik. BIOMA. 17(2):106117.

Irvany, PN. 2011. Penerapan teknologi pertanian padi organic di kampung Ciburuy, Desa Ciburuy, Kecamatan Cigombong, Kabupaten Bogor. [Skripsi]. Fakultas Ekologi Manusia. Institut Pertanian Bogor.

Kartini, N.L. 2001. Strategi meningkatkan dan melestarikan kesuburan tanah berkelanjutan. Ceramah Agroindustri dan Agribisnis. Dinas Koperasi Bali. 15 Agustus 2001. 14 halaman.

Natawigena, H. 1990. Pengendalian Hama Terpadu (Integrated Pest Control). Armico, Bandung.

Pajarina, AR. 2014. Perkembangan populasi hama pada sistem padi organik dan sistem padi konvensional di Ngawi, Jawa Timur. [Skripsi]. Fakultas Pertanian. Institut Pertanian Bogor.
Prihtanti, TM, S Hardyastuti, S Hartono, dan Irham. 2013. Multifungsi sistem usahatani padi organik dan anorganik. Jurnal AGRIFOR. 22(1):11-21.

SAS Institute. 1990. SAS/STAT User's Guide Version 6. Fourth Edition. Volume 2. SAS Institute Inc, North Carolina.

Supartha, IW, dan NL Kartini. 2001. Konsep dan strategi pengembangan pertanian organik di Bali. Seminar Regional Pertanian Organik dan Prospek Pengembangannya di Bali. HUT XXXIV dan BK XXIII Fakultas Pertanian Universitas Udayana. Denpasar. 22 halaman.

Suprijadi, dan Abdulrachman. 1999. Pengaruh penambahan jerami pada pertanaman padi IP 300 terhadap pertumbuhan dan hasil padi sawah irigasi varietas IR36. Prosiding Seminar Nasional Pertanain Organik. Universitas Lampung. Halaman 101-108.

Sutanto, R. 2002. Pertanian Organik Menuju Pertanian Alternatif dan Berkelanjutan. Kanisius, Yogyakarta.

Untung K. 2010. Diktat Dasar-dasar Ilmu Hama Tanaman. Universitas Gajah Mada, Yogyakarta.

Visalakshmi, V, PRM Rao, and NH Satyanarayana. 2014. Impact of paddy cultivation systems on insect pest incidence. Journal of Crop and Weed. 10(1):139-142. 